This is the final peer-reviewed accepted manuscript of:

Howarth, D. and Quaglia, L. (2018) 'Brexit and the battle for financial services', Journal of European Public Policy, 25, 8, pp. 1118-1136.

The final published version is available online at https://doi.org/10.1080/13501763.2018.1467950

Rights / License:

The terms and conditions for the reuse of this version of the manuscript are specified in the publishing policy. For all terms of use and more information see the publisher's website.

\title{
Brexit and the battle for financial services
}

David Howarth, University of Luxembourg

Lucia Quaglia, University of Bologna

\begin{abstract}
This paper analyses the policy developments concerning the Single Market in finance in the context of Brexit. Theoretically, we engage with two bodies of work that make contrasting predictions on European financial market integration and the development of European Union (EU)policies on financial regulation: on focused upon a neo-mercantilist 'battle' amongst member states and the other stressing the importance of transnational financial networks (or coalitions). Empirically, we find limited evidence of the formation of crossnational alliances in favour of the United Kingdom (UK) retaining broad access to the EU Single Market in financial services, the presence of which would have aligned with the expectations of analyses focused upon transnational networks. By contrast, the main financial centres in the EU27 and their national authorities competed to lure financial business away from the UK - what we explain in terms of a 'battle' amongst member states and their national financial centres.
\end{abstract}

KEYWORDS Brexit; financial services; financial regulation; European Single Market; France; Germany

\section{Introduction}

The United Kingdom (UK) is the world's largest exporter of financial services and approximately one third of that export goes to the European Union (EU). Hence, the decision of the UK government to leave the EU triggered widespread concern on the future of the financial sector, both in the UK and in the EU. Key issues concerned both the impact of Brexit on the financial sector in the UK and in the EU27; and the political bargaining power that this would give to the UK and the EU during the Brexit negotiations. The academic literature on the political economy of finance and the politics of financial regulation in the EU makes contrasting predictions concerning these key issues. A neomercantilist state centric body of academic work that emphasises the competition amongst the member states and their financial centres in the EU (Story and Walters 1997; Fioretos 2010; Howarth and Quaglia 2013) would predict that the limitation of access to the Single Market following Brexit would encourage the relocation of financial activities to other EU financial centres, which would therefore seek pro-actively to lure business from London. More generally, this body of work predicts 
that any piece of EU financial regulation that potentially has significant distributive consequences largely but not entirely due to the make-up of different national financial systems — will result in a 'battle' amongst member states. By contrast, a second body of academic work that draws from the literature on transnational finance (Mügge 2010; Macartney 2010; van Apeldoorn 2002) and the new interdependence (Farrell and Newman 2016; Newman and Posner 2016) would predict that crossnational alliances would mobilise in favour of the UK retaining broad access to the Single Market.

In this paper, we ask whether Brexit triggered a 'battle for finance' amongst the member states and their financial centres to attract business from the UK, or whether cross-border coalitions mobilised with a view to securing as much market access as possible and why this was the case. This issue is of immense economic and political significance given the potential impact of Brexit negotiation outcomes on the development of a key economic sector - the financial sector - in the UK and the EU. An examination of this issue also provides a valuable opportunity to speak to the broader academic debate on the relative importance of state-centric explanations versus transnational network explanations of the development of financial governance in the EU and elsewhere.

This paper is structured as follows. We first review the literature on the politics and political economy of financial market integration in the EU. We then map the preferences and the mobilisation of various parts of the financial industry in the UK, as well as the positions to date (February 2018) of the UK authorities during the Brexit negotiations on finance. We do the same with reference to the other two main EU member states, namely Germany and France which, respectively, had the second and third largest financial sectors in the EU and, in Frankfurt and Paris, respectively, had the third and second largest financial centres in the EU by total assets. These were also the most influential member states in the context of Brexit negotiations. We recognise that a number of other second-tier EU27 financial centres and member states with significant financial sectors had the potential to gain from Brexit notably Dublin (Ireland), Brussels (Belgium) and Amsterdam (the Netherlands) and Luxembourg. However, given limited space we do not focus upon these. Empirical material was gathered though a systematic survey of press coverage and policy documents, as well as semi-structured interviews with representatives EU-headquartered banks, EU-based banking associations, business associations, and national government officials responsible for financial affairs.

Our findings suggest that the main financial centres in the EU and their national authorities competed to lure financial business away from the UK, in line with the 'battle' amongst member states approach. In contrast, the formation and mobilisation of cross-national alliances in favour of the UK retaining broad access to the Single Market in financial services mostly failed to materialise, contrary to the expectations of the transnational finance and the new interdependence approach. The main caveat of our analysis is that the Brexit negotiations are ongoing at the time of writing. Yet, a broadly convincing argument on the positioning of financial interests and national authorities can be already presented a year intothe negotiations.

\section{State of the art on the political economy of European financial market integration}

We consider two alternative explanations, which are rooted in the literature on the politics and political economy of EU financial integration. The first explanation is mostly statecentric and focuses on the competition amongst member states and their financial centres in order to attract financial business in the Single Market. The early literature on the 'battle of the systems' (Story and Walter 1997) argues that the national authorities seek to promote EU financial integration in a way that protects their national varieties of financial capitalism. Although national financial systems have partly converged across the EU over time, distinctive features remain. Hence, a more recent version of this literature points out the competition amongst member states to ensure that EU financial regulation does not penalise their financial industry or important parts of it, such as hedge funds in 
the UK (Fioretos 2010), or savings banks in Germany (Howarth and Quaglia 2013). Moreover, the member states might undertake domestic reforms that make their financial centres more attractive (for example, Lutz 1998).

According to this approach, in the context of Brexit, we would expect a neo-mercantilist 'battle' for finance between the UK-based financial industry, notably the City of London, and other EU financial centres, and among these other finance centres, jostling for position to attract business from London, with support from their respective national authorities. More specifically, one would expect attempts of the EU (and the main member states therein) to restrict the ability of UK-based firms to provide a range of financial services, including clearing, to the rest of the EU because this would encourage the relocation of these financial activities to the main financial centres in the EU.

Second, one would expect that each financial centre would seek to play to its comparative advantages because what it could gain from Brexit in terms of new financial operations depended largely on the national variety of financial capitalism. Consequently, Germany and France would be well positioned to attract business in banking, as they would have - post- Brexit - respectively, the first and second largest banking sectors by total assets in the EU, with the concentration of sophisticated investment banking activities in Frankfurt and Paris. Furthermore, Paris and to a lesser extent Frankfurt were well-positioned to attract the clearing of euro denominated derivatives in case the EU - and more specifically the euro area and the ECB - adopted restrictions on euro clearing.

However, continental financial centres were far less appealing than London in most of these financial services for a number of reasons: notably, the concentration of expertise in London, the UK's comparatively light-touch regulatory framework, advantages linked to the use of English common law, and the country's established financial infrastructure. Brexit created an incentive for the national authorities to attempt to woo business from London by making certain features of the national financial system - notably regulation - and related areas — notably tax policy - more appealing to UK-based financial services. Hence, one would expect some domestic reforms in this direction.

The alterative explanation examined in this paper draws on the literature on transnational finance (Graz and Noelke 2008; Mügge 2010; Macartney 2010; Tsingou 2008), whichconsiders EU financial integration as a reflection of the interests of big financial companies,first and foremost British, French and German banks, whose businesses had become pan-European (see also Van Apeldoorn 2002) and the literature on 'new interdependence' (Farrell and Newman 2016; Newman and Posner 2016; Farrell and Newman 2017), which examines the formation of cross-border coalitions brought together by mutual interdependence. For example, in the EU context, Posner (2009) and Quaglia (2010) consider the role of transnational networks (or coalitions) in the making of EU financial regulation over the last two decades.

These two bodies of work pay attention to the mobilisation of transnational networks (coalitions) of private and public actors seeking to protect and expand cross border flows. For example, Farrell and Newman (2014) explain how transnational coalitions generated by financial interdependence were instrumental in settling transatlantic regulatory disputes in finance. According to this literature, in the context of Brexit, we would expect financial firms engaged in cross-border business in the UK and the EU to mobilise because their profits would be reduced by limited access to the single market post Brexit. Hence, we would expect the formation of a transnational coalition lobbying on both sides of the Channel with a view to preserving as much as possible the current level of market access between the UK and the EU, securing a special deal for finance.

We would also expect that this industry coalition would be spearheaded by the main EU-level lobby groups representing the interests of cross-border finance. Moreover, since London is the fulcrum for 
the more internationally-oriented financial firms in Europe, we would expect that these UK-based financial associations would seek to mobilise their counterparts in the EU and that the UK public authorities would also seek to elicit the involvement of the EU based financial industry with a view to preserving as much market access as possible.1

\section{The UK and the Single Market in Finance}

After the referendum, the priority for the bulk of the UK-based financial industry was to preserve membership of and full access to the Single Market. It soon became clear that a European Economic Area (EEA) style arrangement post-Brexit was not feasible for the UK government because of its commitment to ending free movement of labour. As its main alternative, the UK-based financial industry favoured a special deal for finance which, however, was not politically feasible for the EU Commission and several member states, which insisted publicly on maintaining all four freedoms of the internal market or none. Hence, the British financial industry called for the preservation of as much market access as possible (The CityUK 2016a, b). The Conservative government's 'Brexit White Paper' of February 2017 (UK government 2017) made clear that the UK would not seek Single Market membership after Brexit. Nonetheless, the White Paper also highlighted 'a legitimate interest in mutual cooperation arrangements that recognise the interconnectedness of markets' (p. 42) in finance.

Once the UK government outlined its plan for a hard Brexit in early 2017, the UK-based financial industry recognised that it would not be able to preserve the EU passport. Hence, most British financial services campaigned in favour of an extensive use of equivalence, 2 in order to secure as much access as possible to the Single Market (see, for example, Ford 2017). The City also asked for a long transition period out of the Single Market (The CityUK 2016a, b). The strategy adopted by the UK-based financial industry was to point out that it provided a variety of services to 'customers' across Europe and that those services were necessary and could not be easily switched to other locations. Moreover, the City argued that restrictions imposed on British financial services to access the Single Market or to clear euro denominated assets would result in higher costs and more risks for customers across the EU.

According to the 'battle' amongst member states approach, given the economic strength of the financial industry in the UK, one would have expected that the UK government would try to protect this sector by securing continued broad access to the Single Market after Brexit. However, the UK government downplayed the preferences of the UK-based financial industry. Three clarifications regarding the limited influence of the financial industry in the UK must be made. First, the negotiations on finance were part of a broader set of negotiations, whereby it would have been politically difficult for the UK government to grant finance a special status. Second, there were divisions within the UK government, whereby the Chancellor of the Exchequer was more sympathetic than other parts of the government of the concerns of the financial industry. Third, the UK financial industry was not united on the issue of Brexit (see James and Quaglia 2017). Different parts of the financial industry would be impacted by Brexit in different ways, and the parts most likely to be badly affected were those that mobilised the most. The UK-based financial services most potentially affected were wholesale - not retail - because wholesale business is international and cross-border in nature. Thus, the financial services most affected by Brexit would be investment banking and clearing in euro.

The four largest UK banks - HSBC, Royal Bank of Scotland (RBS), Barclays and Lloyds TSB opposed Brexit. However, they were not very vocal in their opposition following the June 2016 referendum because they made limited use of the passport, their UK customer base included Brexit supporters and they did not want to antagonise the UK government (James and Quaglia 2017). 
Throughout 2017, UK banks announced 'contingency plans' to move staff and operations to the EU27, in the event that Brexit negotiations did not ensure full access to the Single Market. Lloyds bank stated that it planned to convert its German branch in Berlin into a subsidiary, and so did Standard Charter with reference to its branch in Frankfurt. HSBC moved to enlarge its existing subsidiary in Paris and RBS announced similar plans with regard to its subsidiary in Dublin. Barclays announced its decision to establish a subsidiary in Dublin.

Big non-EU banks - first and foremost US banks - used the UK as a point of entry into the Single Market through UK-based subsidiaries that then branched out or conducted crossborder business in the EU. Approximately 90 per cent of both European turnover and employees of the five large US investment banks (Goldman Sachs, JP Morgan, Citigroup, Morgan Stanley, Bank of America Merrill Lynch) were located in London (Schoenmaker and Véron 2016). US banks were vocal opponents of Brexit, especially a hard Brexit, and were less restrained than UK banks in voicing their concerns publicly in the media and vis-à-vis the UK government, especially the Treasury. US banks preferred to lobby individually in the UK and announced plans to open offices in Frankfurt.3 The degree to which these announced plans were part of a bank lobbying campaign to influence the UK government's negotiating position was unclear. To date, details on most bank staff transfers and office space expansion remained unclear. According to a number of sources, most banks were 'looking to minimise expense and disruption by relocating as little as possible in the first instance' (Oliver Wyman 2017; interview, Brussels, October 2017).

The other part of the UK financial sector that would be badly affected by Brexit, especially a hard Brexit, was derivatives clearing. Indeed, if clearing restrictions were imposed by the EU in the context of Brexit, the LCH.Clearnet Group would have a clear incentive to move its euro denominated clearing business from London to Paris or Frankfurt. This partly explains why the French and German governments were keen to restrict euro denominated clearing outside the EU, as elaborated in the following section. Hence, the London Stock Exchange (LSE), which was the main owner of LCH.Clearnet, repeatedly pointed out the need to avoid clearing restrictions in the context of Brexit (see, for example, Burton 2017).

\section{The EU27 and Brexit: Defending collective and national interests in finance}

In the aftermath of the referendum, four interrelated dynamics in the EU27 are noteworthy. First, the European Commission, the Parliament and the EU27 member states, made clear that the four freedoms were indivisible and that there would not be a special deal for finance. The EU negotiating guidelines adopted by the European Council (2017, p. 3) stated that 'Preserving the integrity of the Single Market excludes participation based on a sector-bysector approach ... there can be no "cherry picking"'. Second, the Commission (2017) proposed the tightening up of the procedures for assessing equivalence for 'high impact third countries for which an equivalence decision may be used intensively by market operators' - notably the UK. The position of the member states on this tightening varied. While public official statements on equivalence are rare, French Ministry of Finance officials (interview, 16 June 2017) argued that equivalence rules had been excessively watered down in legislation - as in the Alternative Investment Fund Managers directive - and should be reinforced especially for 'high impact' third countries. The explicit French aim was to encourage UK firms to relocate operations to Paris. Certain other member states (interview, Ministry of Finance, Luxembourg, 29 June 2017), however, saw no need to reinforce equivalence rules.

Third, the European Central Bank (ECB), supported by the French and German central banks and governments, re-opened the issue of restricting the bulk of clearing of euro denominated assets to the EU - if not the euro area (Financial Times, 15 January 2017). In the aftermath of the Brexit referendum, French President François Hollande and the Governor of the Bank of France, François 
Villeroy de Galhau stated on separate occasions that the UK would not be able to retain its key role in clearing euro denominated assets (Skolimowski 2016). In early 2017, Andreas Dombret (2017a) - a member of the Executive Board of the German Bundesbank - argued in favour of 'having the bulk of the clearing business inside the euro area'. In June 2017, the ECB, with the support of the Commission, proposed a change to its statutes that would give it and other euro area central banks a clear legal competence in the area of central clearing.

Third, the main financial centres and their public authorities began to mobilise to attract business, as detailed below. In May 2017, the European Securities and Markets Authority (ESMA 2017) issued guidance aimed at avoiding competition on regulatory and supervisory practices between member states, and a possible race to the bottom in the context of Brexit. ESMA subsequently developed sector-specific guidance concerning alternative investment funds, assets management and securities trading. Concerns about a potential race to the bottom and supervisory inconsistencies were also aired by the ECB and the Single Supervisory Board (SSB). In April 2017, the ECB published detailed guidance on several Brexit-related queries, stating that it was concerned with ensuring consistent supervision throughout the euro area and that the ECB would not give out licenses to "empty shell companies' (ECB 2017a).

In France, the Governor of the Bank of France, Villeroy de Galhau, publicly proclaimed Brexit an opportunity for the euro area and an opportunity for the Paris financial centre (Cuny 2017). In September 2016, the former Governor of the Bank of France, Christian Noyer was appointed as 'France's Brexit point man' with the explicit mission of attracting financial business to Paris. In the same month, the Autorité de contrôle prudentiel et de resolution (ACPR) - which monitors banks and insurers - and the Autorité des marchés financiers (AMF) — which safeguards investments and the stock market — issued a joint statement saying they were 'getting ready to welcome British-based institutions that wish to locate their business in France' (ACPR and AMF 2016). The joint statement specified that the licensing procedure would be simplified by using documents already available in English that have been submitted to the supervisory authorities in the home country, namely the UK. The heads of French banks unanimously claimed that they were not preoccupied with the potential destabilisation of Brexit and rather saw it as an opportunity for the French banking system, notably through the repatriation of certain operations undertaken by French banks in London (de Guigné 2017; interview with bank official, Paris, November 2017). Furthermore, the FBF pointed out 'the need to create an ecosystem favourable to banks in order to attract them to Paris' (authors' translation) (Barbat Layani 2017). Despite the public expression of limited concern, French banks had the third largest exposure to the UK economy of any EU country's banks (after Germany and Spain).

In November 2016, Europlace produced a report 'Brexit: La Place de Paris en pôle position en Europe pour attirer les entreprises' (Europlace 2016). By using 12 criteria for the evaluation of financial centres, the report suggested that except for two criteria, Paris ranked higher than Frankfurt. However, in June 2017, a French Senate commission produced a report (de Montgolfier 2017) that argued that French reforms adopted to date were insufficient to make France (Paris) attractive to international financial firms and more needed to be done. With the election of a pro-finance Emmanuel Macron as President, the new French government announced a number of additional reforms to make Paris more attractive to international finance, including lower corporate taxes, reform to the wealth tax, the elimination of the highest bracket of payroll tax on employees, the cancellation of a planned extension of the financial transaction tax, the reduction of additional regulatory burdens, and the creation of a new commercial court for 'highly technical' legal disputes. The new prime minister, Edouard Philippe made the broader promise of keeping financial regulation to a minimum, insisting that France would move on from a past of 'over-regulation' (Bright 2017). 
In Germany, national policy-makers were eager to attract potential financial business from London. German Finance Minister Schäuble discreetly supported the City of Frankfurt's efforts to attract thousands of bankers (O'Donnell 25 January 2017). In January 2017, German banking regulators met more than 20 foreign banks to spell out requirements to move operations to Frankfurt. The meeting was hosted by financial supervisory authority, the Bafin, which made clear that no 'letter-box' operations would be accepted and that banks would have to have significant risk management arrangements and senior executives based in Frankfurt (a point also made separately by the Bundesbank).

The President of the Association of German Private Banks (2016) optimistically stated that the was 'confident that Frankfurt [would] benefit from Britain leaving the EU'. The German Association of Private Banks (2017) indicated that German banks would be relocating various operations from London to Germany over the next two years and that this was 'relatively straightforward from a regulatory and organisational point of view'. Yet, although the bulk of German banks were domestically oriented, the UK was the second-most important foreign market for German banks, immediately following the US. Moreover, German banks had significant exposure to the UK - about 22 per cent of German GDP. In the meantime, UK banks' exposure to German counterparties, represented 12 per cent of UK GDP. Similar to the actions of the French Europlace, the Frankfurt Finanzplatz commissioned the study 'Brexit - Let's go Frankfurt' to Helaba Financial Centre (Helaba 2016). The study compared European financial centres, ranking Frankfurt in second place behind London. Like Paris, Frankfurt was keen to attract clearing derivatives business, as stated by the head of Finanzplatz Deutschland, Hubertus Väth (Colson 2017). In October 2017, Deutsche Börse moved to attract the clearing of euro denominated derivatives contracts from London by changing its clearing rules.

\section{An overall assessment: 'Battle' amongst member states or transnational coalitions?}

The explanation based on transnational financial networks and the new interdependence fits well with the arguments used by the Bank of England, the UK government, and part of the UK based financial industry (e.g. LSE). For example, the Governor of the Bank of England, Mark Carney (2017a,b) argued that there was a mutual interest in a special deal for finance given that London was the 'investment banker' for the EU. Carney $(2017 \mathrm{a}, \mathrm{b})$ also warned against the fragmentation of the global markets by jurisdiction or currency on the grounds that this would reduce the benefits of central clearing. The chairman of the LSE (Rolet 2016) pointed out that the disaggregation of the euro component of the LCH interest rate swap engine Swap Clear would cost the financial services industry $\$ 77$ billion of additional margins (a similar point was made in a policy paper by the Intercontinental Exchange (ICE 2016)).

The ECB (2017) and some national central banks and regulatory agencies explicitly downplayed and / or challenged concerns about the implications of Brexit for financial stability or credit provisions in the EU27. For example, in November 2016, Bundesbank Executive Board member, Andreas Dombret (2016) pointed out that it is often argued that if Brexit hampered the banking sector, it might impair the financing of the European economy. I don't share those fears. Brexit and its possible repercussions for the City of London are unlikely to be an issue for financial stability or the financing of the EU's real economy.

French authorities — both in the public sector and banking sector — were generally unwilling to raise the prospect of EU-wide financial instability caused by Brexit (interview, banking association official, Paris, November 2017), despite the high level of financial integration between the French and UK economies - albeit lower than between Germany and UK. The French government and ministry of finance also took hard line on the need for a tough EU negotiation position with the UK 
and the sanctity of the Single Market. In contrast, the German Ministry of Finance prepared a study (internal paper), stressing that Germany had a considerable interest in an 'integrated financial market' with the UK - given the high level of financial integration between the UK and German economies — but this was to be subject to the latter respecting EU regulatory conditions (Boerse-online.de, 27 March 2017).

As for private actors, one of the main European financial lobbying groups - the Association for Financial Markets in Europe (AFME) - campaigned in coordination with City lobbying groups (including the British Bankers' Association (BBA)) in favour of a long transition period for finance (AFME 2017). The AFME argued that Brexit created particular uncertainty for cross-border wholesale banking. The other main European financial lobby group, the European Bankers' Federation (EBF) - which represents 32 national banking associations - adopted a more neutral position but nonetheless encouraged both the EU27 member states and UK to provide clarity and certainty on Brexit and financial matters as soon as possible to diminish the risk of financial instability (interview with a major EU27 national banking association official, Brussels, 15 November 2017).

There is no publicly available evidence to date that any EU27 national financial associations or major financial companies sought to form a transnational coalition with financial sector actors across the Channel to put pressure on EU and member state authorities to reach a special deal on finance. A number of interviewees explicitly noted the lack of a transnational coalition and the tendency of EUheadquartered banks and associations to be sensitive - albeit reluctantly - to different national government positions. The problem in these EU associations has been that each industry national segment looks closely at the political position of their home country and tends to align with it. So those who are headquartered in a country that sees Brexit as an opportunity to attract business away from London tend to disengage from any effort to find common solutions (interview with UK bank official, Brussels, 17 November 2017). Their silence [on the costs of Brexit to EU27 banks] is surprising to some extent. But it is a deeply uncomfortable territory for companies. Companies are usually cautious with politics, and Brexit is the most political thing happening in a long time, so I can understand their silence. They doubt whether they can have any influence on it and they wonder how they might be thanked for it afterwards (interview with UK bank official, Brussels, 17 November 2017).

A French bank official (interview, Paris, 29 November 2017, authors' translation) remarked that: our only real concern is to not rise above our station, not to interfere with the political debate, which is very tense because potential political costs are very high. We merely are merchants. Hence we focus on technical points, we do not comment on (dis)agreements between governments. An official of a major EU27 banking association (Brussels, 15 November 2017) reiterated that: 'A deal on finance that would leave us as close as possible to the previous situation would be the preference of [national association] members, but we have to be aware that this is impossible due to political forces, and prepare for no deal'. Officials from several major EU financial associations also noted their frustration with the prioritisation of national politics over a deal that would minimise disruption. Some officials specifically targeted French companies: the French government and the broader French establishment have taken a very strong stance on Brexit. ... It feels like the political position of the French banking sector is defined in the Elysée [the French president's office] and passed on to the banks. When we talk to French banks individually, they seem to worry about the consequences of Brexit, but collectively there is not a word of that (interview, EU financial association officials, Brussels, 21 November 2017).

A number of EU27 national associations met with the UK-based International Regulatory Strategy Group (IRSG) and the UK bank lobby group UK Finance to discuss proposals for a 'mutual access' agreement (see also Financial Times, 3 July 2017). However, the widespread view of these national 
associations was that certain EU27 governments would not 'let this fly' and these transnational efforts fizzled out (interview with a major EU27 national banking association official, 15 November 2017). This absence of a transnational coalition and the alignment with national government positions remains surprising given widespread support in EU27-headquartered banks and national banking associations for a special carve out on finance and concerns regarding the significant predicted costs of having to capitalise their UK branches which, without a special deal on finance, would potentially have to be transformed into subsidiaries. However, in December 2017, the Prudential Regulation Authority provided reassurances concerning the treatment of branches of European banks in the UK after Brexit (Jack 2017), although the implications (and the costs for European banks in the future) remained to be seen.

US-headquartered financial institutions, acting alone or in coordination with US public authorities, encouraged a special deal on finance. US banks were concerned about the cost of establishing or expanding subsidiaries in the EU because the large majority of these banks lacked capitalised subsidiaries in the EU. US bank efforts were largely channelled through the AFME, whose chairman was Michael Cole-Fontayne, head of Europe at Bank of New York Mellon. The AFME appears to have been the most important group leading transnational efforts to push for a special deal for finance (Martin 2017; Williams-Grut 2017).

There was a 'battle' between the main financial centres in the EU in order to lure business from London, building on national competitive advantages mainly resulting from the configuration of national financial systems. The main continental financial centres, first and foremost Paris and Frankfurt, competed very directly with each other in order to attract business from London. For example, at an event in London in October 2016, representatives of business lobbies from both Paris (Europlace) and Frankfurt (Finanzplatz Deutschland) pitched hard to the business community that their cities should be the preferred destination for relocation (Business Insider, 19 October 2016). Rivalries among EU financial centres and among their member state government backers also surfaced in the case of euro clearing, where German, French and Italian policy-makers argued that the ECB should only be given authority over any clearing house still outside the EU (Canepa and Koranyi 2017). Overall, EU institutions adopted official neutrality on the attractiveness of different EU financial centres.

It is puzzling that in the case of Brexit there was a battle for financial services amongst the member states, while at the same time an EU-wide transnational coalition did not materialise. This is unlike what happened, for example, in the re-launch of the completion of the single market in finance prior to the international financial crisis. Two factors account for this battle and absence of transnational coalition: the political salience of Brexit and the competing financial interests that Brexit generated. First, Brexit was an issue of high 'salience' for politicians and public opinion in the UK and EU, whereas the financial industry traditionally yields more influence on matters of 'quiet politics' (Culpepper 2011). The influence of powerful economic interests is high when decisions are largely insulated from political pressures (Culpepper 2011; Pagliari 2012), but it declines when decisions face greater public scrutiny. In this context, politicians are more likely to respond to voters' concerns than to financial industry structural and instrumental power. The high political salience of Brexit reduced the willingness of politicians to listen to business concerns and therefore limited the incentives and ability of the financial industry on both sides of the Channel to lobby for a special deal in finance.

The UK government was less sympathetic to the Brexit-related concerns raised by the financial industry than it was on most national and EU regulatory issues. James and Quaglia (2017) report that City lobbyists found it difficult to access the Prime Minister's office and that business groups would be 'frozen out' if they were too negative on Brexit. In the EU, national political authorities made clear 
that there would be no cherry picking of the Single Market (especially for finance) and that they expected their national business communities to support the positions taken by their respective national governments. For example, at the beginning of the Brexit negotiations in June 2017, Chancellor Merkel warned the German business community to 'hold firm' and 'don't let anyone drive a wedge between us' (Delfs 2017).

Second, the financial industry in the UK and EU27 had (partly) competing interests. The main financial centres in the EU27 had an interest in attracting business from the UK, whereas the UKbased financial industry had the opposite interest. Moreover, when trade associations and individual UK and US banks sought to liaise with their counterparts in the EU, they were perceived as making the case for a special deal in finance on behalf of the UK government (James and Quaglia 2017). The financial industry and regulators on both sides of the Channel also had an interest in avoiding major disruptions in cross-border financial flows, the functioning of the single market in finance and financial stability. Yet, politics appears to have trumped economics in the context of Brexit.

The two theoretical frameworks applied in this paper are focused in large part upon dynamics created by financial interests. However, one should be aware of the explanatory limits of these two frameworks. Indeed, certain aspects of the negotiations concerning Brexit and finance - for example, the decision of the UK government to downplay the calls of parts of the City of London for a soft Brexit and the concerns raised by the ECB against continuing to rely on the City as the main centre for the clearing of euro denominated swaps - cannot be adequately explained by these two theoretical frameworks.4 Nonetheless, a neo-mercantilist 'battle' amongst member states approach remains the most convincing explanation for the positioning of the German and French governments and their financial centres.

\section{Conclusion}

In this paper, we have used two main theoretical approaches derived from the existing literature on the political-economy of European financial integration to shed light on the implications of Brexit for finance and the dynamics that have been unleashed. Our findings suggest that some 'transnational alliances' on the subject of finance and Brexit were formed as the result of financial interdependence. Yet, these alliances were limited in scope and failed to involve or mobilise significantly EU private and public sector actors. In the private sector, the AFME — one of the main EU-level lobbying groups - and several UK-based financial associations argued for a long transition period for finance following the conclusion of Brexit negotiations and, ideally, a special deal on finance. In the public sector, a number of German (and other EU27) officials noted their awareness of the importance of the City of London in European finance and reiterated the arguments presented by both UK public authorities and a range of UK-based financial companies and their representative associations. The main caveat to be noted with regard to this conclusion about the lobbying efforts and demands of international finance, is that it remained possible that transnational coalitions involving EU partners could gain momentum as Brexit negotiations progressed.

There is far greater evidence of a neo-mercantilist 'battle' amongst member states, with individual national governments promoting their financial centres and competing to attract financial operations from the UK. In the largest member states, Frankfurt was touted as the main destination for banks. French efforts to improve the attractiveness of Paris had limited success to the time of writing (February 2018), although the 2017 election of Emmanuel Macron boded well for further reform. In this context, the EU authorities, namely the Commission and the ECB, were keen to preserve the integrity of the Single Market and its four freedoms. They sought to prevent a regulatory 'race to the bottom' in finance - with financial centres and national authorities attempting to undercut each other — thus undermining longstanding efforts to construct a level playing field across the EU. 


\section{Notes}

1 We wish to thank an anonymous reviewer for this point.

2 Equivalence rules stipulate that unless third country rules are equivalent to EU rules, foreign firms providing services in the EU or doing business with EU counterparts would be subject to EU regulation in addition to their home country regulation. Without equivalence, foreign firms failing to respect EU regulations would be blocked from accessing the Single Market.

3 According to Frankfurt Main Finance - the main financial sector promotion body of the City of Frankfurt - quoted in the Handlesblatt, 26 April 2017.

$4 \mathrm{We}$ wish to thank an anonymous reviewer for this point.

\section{Acknowledgements}

The authors would like to thank Sébastien Commain - currently a doctoral student at the University of Luxembourg and research assistant to Professor Howarth — for his help conducting a number of interviews with financial company and association representatives in Brussels and Paris. This paper was partly written while Lucia Quaglia was a research fellowat the Scuola Normale Superiore, Florence.

\section{Disclosure statement}

No potential conflict of interest was reported by the authors.

\section{Notes on contributors}

Lucia Quaglia is Professor of Political Science at the University of Bologna; lucia.quaglia@ unibo.it David Howarth is Professor of Political Economy at the University of Luxembourg;david.howarth@uni.lu

\section{References}

ACPR and AMF (2016) 'L'ACPR et l'AMF simplifient et accélèrent les procédures d'agrément dans le contexte du BREXIT', Communication de presse, 28 Septembre, available at https://acpr.banquefrance.

fr/fileadmin/user_upload/acp/Communication/Communiques\%20de\%20presse/201609

28-CP-ACPR-AMF-agrements-Brexit.pdf.

AMFE (Association for Financial Markets in Europe) (2017) 'Implementing Brexit:

Practical challenges for wholesale banking in adapting to the new environment', April, available at https://www.afme.eu/globalassets/downloads/publications/afme-implementingbrexit2017.pdf.

Association of German Private Banks (2017), Press statement, available at https://bankenverband.de/newsroom/presse-infos/impact-brexit-german-banks-will-belimited/. Association of German Private Banks (2016) Press statement, available at https://bankenverband.de/newsroom/presse-infos/president-association-german-banksregretsdecision-brexit/.

Asimakopoulos, P. and Wright, W. (2017) 'What the rest of the EU thinks about Brexit and the City of London', New Financial, available at 2017.04-What-the-rest-of-the-EU-thinksaboutBrexit-New-Financial-FINAL1.pdf.

Barbat Layani, M.A. (2017) Press statement, available at http://www.fbf.fr/fr/espacepresse/ 
interventions-de-la-fbf/marie-anne-barbat-layani-au-iveme-forum-du-grand-paris---ilfautcreer-un-ecosysteme-favorable-aux-banques-pour-les-attirer-a-paris.

Batsaikhan, U., Kalcik, R. and Schoenmaker, D. (2017) 'Brexit and the European financial system: mapping markets, players and jobs', Bruegel Institute, Policy contribution, Issue 4, available at http://bruegel.org/wp-content/uploads/2017/02/PC-04-2017-finance-090217final.pdf.

Bank of England (2015) 'Mapping the UK Financial System', Bank of England Quarterly Bulletin, Q2, London.

Bieling, H.J. (2003) 'Social Forces in the Making of the New European Economy: The Case of Financial Market Integration', New Political Economy 8(2): 203-223.

Brassac, P. (2017) 'Interview de Philippe Brassac, Président de la FBF, Directeur général de Crédit Agricole SA, pour Revue Banque - "Le système bancaire français est un ilot de stabilité dans un monde d'incertitudes", FBF website, 9 January, available at http://www.fbf.fr/fr/espace-presse/interventions-de-la-fbf/interview-de-philippe-brassac,president-de-la-fbf,-directeur-general-de-credit-agricole-sa,-pour-revue-banque---lesystemebancaire-

francais-est-un-ilot-de-stabilite-dans-un-monde-d'incertitudes.

Bright, R. (2017) 'Paris rolls out 'red-white-and-blue carpet' for banks', Financial Times, 7 July.

Burton, L. (2017) 'LSE fires back at EU plot to seize euro-clearing', The Telegraph, 2 May. Busch A. (2004) National Filters: Europeanization, Institutions and Discourse in the Case of Banking Regulation, West European Politics 27(2): 310-33.

Canepa, F. and Koranyi, B. (2017) 'Exclusive: ECB plan to take euro clearing from London stalled by infighting - sources', 22 May, Reuters, available at http://www.reuters.com/article/us-britain-eu-clearing-ecb-idUSKBN18I1B2.

Carney, M. (2017a), 'Oral evidence', Treasury Committee, House of Commons 11 January. Carney, M. (2017b) 'A Fine Balance, speech at Mansion House', Bank of England, 20 June, London.

The CityUK (2016a) The impact of the UKs exit from the EU on the UK based financial services sector, October, available at https://www.thecityuk.com/assets/2016/Reports$\mathrm{PDF} /$ The-impact-of-the-UKs-exit-from-the-EU-on-the-UK-based-financial-servicessector. pdf.

The CityUK (2016d), Brexit and the industry, September, available at https://www.thecityuk.com/research/brexit-and-the-industry/.

Colson, T. (2017) 'Frankfurt is 'confident in the arguments' for poaching Britain's €930 billion euro clearing industry after Brexit', Business Insider UK, 7 July, available at http://uk.businessinsider.com/brexit-relocation-financial-services-frankfurt-main-2017-7. Commission (2017), 'Commission Staff Working Document EU equivalence decisions in financial services policy: an assessment', Brussels, 27 February.

Culpepper, P. D. (2011) Quiet Politics and Business Power: Corporate Control in Europe and Japan, Cambridge: Cambridge University Press.

Cuny, D. (2017) 'Brexit Paris a toutes ses chances selon Villeroy de Galhau', La Tribune, 29 May.

de Guigné, A. (2017) 'Brexit: Paris veut améliorer sa copie pour attirer plus d'entreprises', Le Figaro, 24 July.

Delfs, A. (2017) 'Merkel Tells German Industry to Hold Firm as Brexit Talks Begin', Bloomberg, 20 June.

Dombret, A. (2016) 'What does Brexit mean for European banks' Keynote Speech at a Conference of the Association of German Banks Center for Financial Studies, Goethe University Frankfurt, 13 July, available at https://www.bundesbank.de/Redaktion/EN/Reden/2016/2016_07_13_dombret.html. 
Dombret, A. (2017a) 'Andreas Dombret: Uncertain times - Brexit and its impact on the financial sector', Remarks to Boston Consulting Group, Frankfurt am Main, 7 February, available at http://www.bis.org/review/r170208a.pdf.

Dombret, A. (2017b) 'Spirit of optimism in Frankfurt', interview published in Der Spiegel, 19 August, available at

http://www.bundesbank.de/Redaktion/EN/Topics/2017/2017_08_21_dombret_spiegel.html. European Central Bank (ECB) (2017a) 'Relocating to the euro area', available at https://www.bankingsupervision.europa.eu/banking/relocating/html/index.en.html. European Central Bank (ECB) (2017b) Financial Stability Review, May, available at https://www.ecb.europa.eu/pub/pdf/other/ecb.financialstabilityreview201705.en.pdf?ce0cddc de1256fb5f6653e8aedf2ebd7.

European Council (2017) 'Special meeting of the European Council (Art. 50) (29 April 2017)

- Guidelines', Brussels, 29 April, EUCO XT 20004/17, BXT 10, CO EUR 5, CONCL 2, available at 29-euco-art50-guidelines.en.pdf.

European Securities Markets Authority (ESMA) (2017) Principles on the supervisory approach on relocations from the UK, available at https://www.esma.europa.eu/pressnews/ esma-news/esma-issues-principles-supervisory-approach-relocations-uk.

Europlace (2016) 'The Paris Marketplace in Pole Position to attract Companies', Press

Conference slides, 29 November, available at http://www.paris29

europlace.com/sites/default/files/public/the_paris_marketplace_in_pole_position__28112016_en.pdf.

Farrell, H. and Newman, A. (2017) 'Brexit, voice and loyalty: Rethinking electoral politics in an age of interdependence', Review of International Political Economy, 24(2): 232-247.

Farrell, H. and Newman, A. (2016) The new interdependence approach: theoretical development and empirical demonstration, Review of International Political Economy, 23(5): 713-736.

Farrell, H. and Newman A. (2014) 'The New Politics of Interdependence: Cross-National Layering in Trans-Atlantic Regulatory Disputes', Comparative Political Studies, 48(4): 497526.

Ferran, E. (2016) The UK as a Third Country in EU Financial Services Regulation, University of Cambridge Faculty of Law Research Paper No 47/2016, available at https://ssrn.com/abstract=2845374.

Fioretos, O. (2010) 'Capitalist Diversity and the International Regulation of Hedge Funds', Review of International Political Economy 17(3): 696-723.

Ford, J. (2017) 'An equivalence deal on Brexit may be the best the City can get', Financial Times, 10 April.

Graz, C. and Noelke, A. (eds.) (2008) Transnational Private Governance and its Limits, London: Routledge.

Helaba (2016) 'Brexit — Let's Go Frankfurt', Financial Centre Focus, 3 November, available at

https://www.helaba.com/blob/com/408348/c00d2e172a25dd521fab5df9e34c795c/financialcentrefocus--brexit---let-s-go-frankfurt-data.pdf.

Howarth, D. (2013) 'France and the International Financial Crisis: The Legacy of State-Led Finance', Governance: An International Journal of Policy, Administration, and Institutions, 26(3): 369-395.

Howarth, D. and Quaglia, L. (2013) 'Banking on Stability: The political economy of new capital requirements in the European Union', Journal of European Integration, 35(3): 333 346.

Howarth, D. and Quaglia, L. (2016) The Political Economy of Banking Union, Oxford: Oxford University Press.

ICE (2016) Access to Global Markets, Working Paper, available at 
https://www.theice.com/publicdocs/ICE_Working_Paper_Access_Global_Markets.pdf. Iskyan, K. (2016) 'China's stock markets have soared by 1,479\% since 2003', in

Businessinsider.com, 6 November, available at http://www.businessinsider.com/world-stockmarketcapitalizations-2016-11.

Jack, S. (2017) 'Brexit: UK plans to soften impact on European banks', $B B C, 20$ December. James, S. and Quaglia, L. (2017) 'Brexit and the Limits of Financial Power in the UK', Working Paper, University of Oxford, available at https://www.geg.ox.ac.uk/brexit-andlimitsfinancial-power-uk.

Lautenschläger, S. (2017) 'Some supervisory expectations for banks relocating to the euro area', Technical workshop for banks considering relocation in the context of Brexit, Frankfurt am Main, 4 May, available at

https://www.bankingsupervision.europa.eu/press/speeches/date/2017/html/ssm.sp170504.en.h tml; accessed on 25 June 2017.

Lütz, S. (1998) 'The Revival of the Nation State? Stock Exchange Regulation in an Era of Globalised Financial Markets', Journal of European Public Policy, 5(1): 153-68.

Macartney, H. (2010) Variegated Neoliberalism: EU Varieties of Capitalism and International Political Economy, London: Routledge.

Martin, B. (2017) 'London and Brussels urged to agree Brexit transition deal to protect banks', The Telegraph, 5 April.

Montgolfier, A. de (2017) 'Places financières : quelle stratégie française face au Brexit ?', Rapport d'information 574 (Report presented to the French Senate), 7 June 2017, available at https://www.senat.fr/notice-rapport/2016/r16-574-notice.html.

Mügge, D. (2010) Widen the Market, Narrow the Competition: Banker Interests and the Making of a European Capital Market, Colchester: ECPR.

Mügge, D. (2006) 'Reordering the Marketplace: Competition Politics in European Finance', Journal of Common Market Studies 44(5): 991-1022.

Newman, A. and Posner E. (2016) 'Transnational feedback, soft law, and preferences in global financial regulation', Review of International Political Economy, 23(1): 123-152. Nouy, D. (2017) 'Introductory statement to the press conference on the ECB Annual Report on supervisory activities 2016 (with Q\&A)', Frankfurt am Main, 27 March, available at https://www.bankingsupervision.europa.eu/press/speeches/date/2017/html/se170327.en.html. O'Donnell, (2017) 'Germany calls bankers to Frankfurt for Brexit move talks', Reuters, 25 January.

Pagliari, S. (2013) Public Salience and International Financial Regulation, Thesis presented to the University of Waterloo.

Posner, E. (2009) The Origins of Europe's New Stock Markets, Cambrdige, MA: Harvard University Press.

Quaglia, L. (2010) Governing Financial Services in the European Union: Banking, Securities and Post-Trading, London: Routledge.

Rolet, X. (2016) 'Oral Evidence, Brexit: financial services', 9th Report of Session 2016-17, European Union Committee, House of Lords, December.

Tsingou, E. (2008). 'Transnational Private Governance and the Basel Process: Banking Regulation, Private Interests and Basel II', in J. C. Graz and A. Nölke (eds), Transnational Private Governance and its Limits. London: Routledge, 58-68.

Schoenmaker, D. (2016) 'Lost passports: a guide to the Brexit fallout for the City of London', Bruegel Institute, Blog, 30 June, available at http://bruegel.org/2016/06/lost-passports-aguideto-the-brexit-fallout-for-the-city-of-london/.

Story, J., and Walter, I. (1997) Political Economy of Financial Integration in Europe: The Battle of the System, Manchester: Manchester University Press.

Skolimowski P. (2016) 'Draghi Says Clearing Oversight After Brexit Is 'Crucial' for ECB', Bloomberg, 29 June. 
UK government (2017) 'The United Kingdom's exit from, and new partnership with, the European Union White Paper', 2 February, available at

https://www.gov.uk/government/publications/the-united-kingdoms-exit-from-and-newpartnershipwith-the-european-union-white-paper.

Van Apeldoorn, B. (2002) Transnational Capitalism and the Struggle over European Integration, London: Routledge.

Williams-Grut, O. (2017) 'Hard Brexit: execs are lobbying Brussels to stop it', Business Insider, 3 July.

Wyman, O. (2017) 'One Year on from the Brexit Vote: A Briefing for Wholesale Banks', available at http://www.oliverwyman.com/content/dam/oliverwyman/ v2/publications/2017/aug/OW-Wholesale-Banking-Brexit-Briefing.pdf. 